\title{
Ameliorative Potential of Methanolic Extract of Clerodendrum infortunatum Linn. in Arsenic Induced Sub-Acute Hepatotoxicity in Albino Rats
}

\author{
Pinki Singh $^{1}$, Raju Prasad ${ }^{2}$ and Shamshun Nehar ${ }^{3}$ \\ ${ }^{1}$ PG Department of Zoology, Ranchi University, Ranchi, Jharkhand, India \\ ${ }^{2}$ Department of Pharmacology and Toxicology, Ranchi Veterinary College, BAU, Ranchi, \\ Jharkhand, India \\ ${ }^{3}$ PG Department of Zoology, Ranchi University, Ranchi, Jharkhand, India \\ *Corresponding author
}

\section{A B S T R A C T}

The present study aimed to investigate the protective effect of Clerodendrum infortunatum

\begin{tabular}{|c|c|}
\hline $\begin{array}{l}\text { Ameliorative, } \\
\text { Clerodendrum } \\
\text { infortunatum, } \\
\text { hepatotoxicity, } \\
\text { rats, Sodium } \\
\text { arsenite }\end{array}$ & $\begin{array}{l}(C I) \text { by targeting its antioxidant properties against liver damage induced by arsenic in rats. } \\
\text { Total } 18 \text { rats weighting } 140-200 \mathrm{~g} \text {, were divided into three groups. Groups representing } \\
\text { control and treatment groups [treated with sodium arsenite alone ( } 3 \mathrm{mg} / \mathrm{kg} \text { b.w. of rats) and } \\
\text { in combination with methanolic extract of } C I \text { leaves }(100 \mathrm{mg} / \mathrm{kg} \mathrm{b} \text {. w.)]; groups named I, II } \\
\text { and III respectively. Sodium arsenite and } C I \text { extracts were administered orally, once daily } \\
\text { over a period of } 28 \text { days. Body wt. of each rats were recorded on day } 0,14 \text { and } 28 \text { days of } \\
\text { the experiment. At the end of treatment period, liver weight were recorded and their } \\
\text { samples were collected for the examination of oxidative stress parameters like superoxide }\end{array}$ \\
\hline Article Info & ed by \\
\hline $\begin{array}{l}\text { Accepted: } \\
\text { 19 April } 2017 \\
\text { Available Online: } \\
10 \text { May } 2017\end{array}$ & $\begin{array}{l}\text { tress, lowers the liver toxicity enzyme marker level and protect the cells which have been } \\
\text { amaged by arsenic toxicity. } C I \text { plays a protective role against arsenic-induced toxicity in } \\
\text { iver and may potentially be used as a remedial agent. }\end{array}$ \\
\hline
\end{tabular}

\section{Introduction}

Arsenic is a metalloid and widespread environmental toxicant. It is potent environmental toxic agent leading to various harmful effects on the human health. People get exposed to arsenic during professional and environmental processes (Ramanathan et al., 2003). Epidemiological studies of human has demonstrated direct relationship between exposure of arsenic compound in drinking water and several types of cancer (Droge, 2002). The accumulation of arsenic generates oxidative stress in the body causing fatal effects to important biological processes leading to cell death. Arsenic toxicity generates reactive oxygen species (ROS) such as hydroxyl radicals $(\mathrm{OH})$, superoxide anions $\left(\mathrm{O}_{2}^{-}\right)$through chain reactions and causing oxidative damage to lipids, proteins and DNA 
of the body (Sarkar et al., 2003). Arsenic induced apoptotic events are triggered by increasing oxidative stress and depletion of endogenous anti-oxidant system (Droge, 2002).Therefore, the anti-oxidant enzyme activity inhibits the antioxidant/oxidant imbalance.

Detoxification of toxic xenobiotics or foreign compounds occurs mostly in the hepatic tissue and to a lesser extent in some extra hepatic tissues. Several studies demonstrated that arsenic toxicity leads to liver injury and the extent of injury to the hepatocytes is generally detected by the activity of ALT, AST, ALP and protein etc. in serum.

Clerodendrum infortunatum Linn., family Verbenacae is a small shrub plant found throughout the plains of India; and in Jharkhand, is found in all districts along the streams, edges of glades and in shady places. This plant has been used in Indian folks medicine; leaves, roots and flowers are used in various diseases and disorders (Dymock, 1976). Therefore, the present study was aimed to investigate ameliorative efficacy of the $80 \%$ methanolic extracts of $C I$ against sodium arsenite induced sub-acute hepatotoxicity in albino rats.

\section{Materials and Methods}

\section{Study groups}

In our study, 18 albino male rats with identical biological and physiological characteristics housed under standard laboratory conditions $\left(22 \pm 2{ }^{0} \mathrm{C}, 12 \mathrm{~h}\right.$ light $/ 12$ $\mathrm{h}$ dark cycle ) were divided into three groups.

Group I (control, $\mathbf{n = 6}$ ): Normal feed and water was provided for 28 days.

Group II (Arsenic induced, $\mathbf{n = 6}$ ): Sodium arsenite @ $3 \mathrm{mg} / \mathrm{kg}$ via stomach tube for 28 days.
Group III (Arsenic+CI extract, $\mathrm{n}=6$ ): Sodium arsenite@ $3 \mathrm{mg} / \mathrm{kg}$ in combination with $C I @ 100 \mathrm{mg} / \mathrm{kg}$ via stomach tube for 28 days.

The liver tissue samples were collected for the study at the end of experimental period.

\section{Plant Collection and preparation of extract}

Clerodendrum infortunatum leaves were collected just after the rainy season from the herbal garden of Ranchi Veterinary College, kanke, Ranchi. The leaves were washed and shade dried for about four weeks, leaves were then pulverized and grinded to powder in mixer grinder. Extraction of $80 \%$ methanol extract of powdered material of $C I$ was done as per the standard method (Panigrahi et al., 2016). The extracts were reconstituted by dissolving the solid mass with double distilled water for the oral administration in rats.

\section{Body weight and liver weight}

Rats of each group were weighed on 0,14 and 28 day up to 28 days and the body weights of individual rats in different groups were recorded. Liver was collected at the end of the experiment and their weight was properly recorded.

\section{Assessment of SOD enzyme activity}

The superoxide dismutase (SOD) activity was assessed according to the method described by Madesh and Balasubramanium (1998). It involves generation of superoxide by pyrogallol autoxidation and the inhibition of superoxide dependent reduction of the tetrazollium dye MTT [3 - (4 - 5 dimethyl thiazol 2-xl) 2.5 diphenyl tetrazolium bromide] to its formazan, measured at 570 $\mathrm{nm}$. The reaction was terminated by the addition of dimethyl sulfoxide (DMSO), which helps to solublize the formazan formed. 
The enzyme activity has been expressed as $\mu \mathrm{M}$ MTT formazan formed / $\mathrm{min} / \mathrm{mg}$ protein, using a molar extinction coefficient of 17000 $\mathrm{M}^{-1} \mathrm{~cm}^{-1}$.The colour evolved is stable for many hours, and expressed as $\mu \mathrm{M}$ of MTT formazan formed/mg protein or U/gm tissue.

\section{Estimation of MDA level}

Lipid peroxidation in liver tissue homogenate was estimated in terms of malondialdehyde (MDA) production by the modified method of (Stock and Dormandy, 1971) as described by (Jain, 1988). $0.5 \mathrm{ml}$ of tissue homogenate was suspended in $0.5 \mathrm{ml}$ of PBS. To this $0.5 \mathrm{ml}$ of $30 \%$ TCA was added. Tubes were vortexed and allowed to stand on ice for at least $2 \mathrm{~h}$. Tubes were centrifuged at $2000 \mathrm{rpm}$ for 15 minutes. $1 \mathrm{ml}$ of the supernatant was transferred into another tube and to this 0.075 $\mathrm{ml}$ of $0.1 \mathrm{M}$ EDTA and $0.25 \mathrm{ml}$ of $0.67 \%$ thiobarbituric acid in $0.05 \mathrm{M} \mathrm{NaOH}$ was added. It was mixed and the tubes were kept in a boiling water bath for $15 \mathrm{~min}$. and then allowed to cool at room temperature. Absorbance was read at $532 \mathrm{~nm}$. The amount of lipid peroxidation is expressed in nanomoles of MDA formed per $\mathrm{mg}$ of protein.

\section{Assessment of Liver toxicity enzyme Test}

The biochemical estimations were done by using Erba Semi-autoanalyzer. ALT and AST in blood was measured by modified IFCC method given by (Sannigrahi et al., 2009). ALT and AST levels were expressed as IU/L.

\section{Statistical Analysis}

The all experimental data were expressed as mean \pm standard error of mean (SEM). Results are expressed as Mean \pm SEM. with $n$ equal to number of animals. Data were analyzed applying one way anova using the GraphPad Prism v4.03 software program (San
Diego, CA, USA), and the differences were considered statistically significant at $* \mathrm{P}<0.05$ or lower (Snedecor and Cochran, 1989).

\section{Results and Discussion}

As shown in Table 1, the body weight of group III were found to be significantly $(\mathrm{P}<0.001)$ increased as compared to their Group II at end of the treatment. The final b.wt of arsenic treated rats were found to increased non-significantly within the group. Group I showed the highest increase in final b.wt followed by Group III and then Group II (Table-1, Fig.-1).

The absolute and relative liver weights of arsenic treated animals were found to be significantly $(\mathrm{P}<0.001)$ lower as compared to control group. In case of Arsenic $+C I$ treated animals the significant $(\mathrm{P}<0.05)$ increase in liver weight was found (Table-2, Fig.-2).

It was detected that a significant reduction was found in the activity of antioxidant enzyme SOD $(\mathrm{P}<0.001)$ on arsenic exposure as compared to control, while the treatment of $C I$, significantly prevented impaired enzyme activity caused by arsenic in the arsenictreated group. A significant increase in SOD value was observed in group III as compared to group II (Table-2, Fig.-3).

The MDA levels and antioxidant enzyme activities in the liver tissue of the groups are totally shown in Table-2. It was monitored that MDA level, being used as an indicator of lipid peroxidation in the liver tissues of rats, significantly increased in the arsenic-treated group compared with control group, whereas MDA level significantly decreased in the $C I$ treated; result is considered to be associated with protective effect of $C I$ against oxidative damage caused by arsenic.(Fig.-4). Serum ALT and AST activity were significantly ( $\mathrm{P}<$ 0.001) higher in arsenic treated group as 
compared to control. Elevated enzyme activity of ALT and AST indicates damage to liver. Significant decrease in serum ALT and AST were observed in group III as compared to group II. Hepatocellular damage and necrosis is ameliorated by $C I$ treatment.(Fig.5\&6)

There was significant reduction in body weight of rats in sodium arsenite treated group in 28 days of experiment. Our results are in agreement with Sharma et al., (2007), where similar results of loss in b.wt gain in arsenic-induced toxicity of Swiss albino mice were observed. Arsenic is highly toxic and corrosive to gastrointestinal tract resulting into partial anorexia and gastro-intestinal disturbances followed by loss of body weight (Klassen, 2001) in arsenic intoxicated animals on day 28. In group III, the reduction in body weight of animals were less as compared to group II indicated $C I$ possess a potent antioxidant activity, reduced oxidative stress and which may be one of the reason for normal increase in body weight in $C I$ treated group.

Liver damage may be associated with production of reactive oxygen species which attack essential cell constituents such as proteins, lipids and nucleic acids (Sharma et al., 2007). Arsenic at high doses causes acute hepatic injury and hepatocellular necrosis causing leakage of hepatocellular enzymes into the blood (Benzamin, 2010) ${ }^{\circ}$ In the present study, improved weight of the liver was observed when sodium arsenite was administered with $C I$. This may be due to hepatoprotective activity of $C I$, which is probably due to presence of flavanoids, that produces hepatocellular membrane stability, prevention of cellular leakage and increasing hepatic regeneration (Sangeetha, B. and Krishna kumari, 2010).

Lipid peroxidation is one of the main manifestations of oxidative damage, which plays an important role in the toxicity of many xenobiotics (Stohs and Bagchi, 1995; Anane and Creppy, 2001). Lipid peroxyl radicals react with other lipids, proteins and nucleic acids, propagating thereby the transfer of electrons and bringing about the oxidation of substrates. Cell membranes, which are structurally made up of large amounts of polyunsaturated fatty acids are highly susceptible to oxidative attack and consequently changes in membrane fluidity, permeability and cellular metabolic functions (Bandhopadhya et al., 1999). Moreover, the end products of lipid peroxidation like malondialdehyde (MDA) can also cause tissue injury by interacting with biomacromolecules (Mylonas and Kouretas, 1999). The products of lipid peroxidation can be easily detected as thiobarbituric acid reactive substances (TBARS) and measured in terms of malondialdehyde production in organ/ blood. In the present study there was increased lipid peroxidation in liver of sodium arsenite treated group. The results were in the correlation with the previous findings by Nandi et al., (2008). The increase in LPO levels may be due to production of free radicals.

Superoxide dismutase is an enzyme that provides cellular protection against the damage caused by free radicals and ROS (Kant et al., 2011). SOD of liver was significantly decreased and increased LPO value in arsenic treated rats as compared to control group were observed. SOD is an antioxidant enzyme, responsible for the elimination of superoxide radical. Its activity depends on $\mathrm{O}_{2}{ }^{-}$concentration in the biological system. SOD catalyses the dismutation of $\mathrm{O}_{2}{ }^{-}$ into oxygen and $\mathrm{H}_{2} \mathrm{O}_{2}$, thus decrease $\mathrm{ROS}$ generation and oxidative stress (Segui et al., 2004). Increased activities of SOD have been reported to scavenge the superoxide radicals to protect the tissue damage by free radicals (Shirwaikar et al., 2003). 
Table.1 Effect of $C$. infortunatum extract on body weight (gms) ( Mean \pm SE) in arsenic induced sub- acute toxicity in rats

\begin{tabular}{|l|l|l|l|}
\hline \multicolumn{4}{|c|}{ Body weight (Grams) (Mean \pm SE) of rats } \\
\hline Days & Day 0 & Day 14 & Day 28 \\
\hline Group I & $154.13 \pm 0.40$ & $175.30 \pm 0.52$ & $198.77 \pm 0.64$ \\
\hline Group II & $154.43 \pm 0.58$ & $172.28 \pm 0.55$ & $190.77 \pm 0.57$ \\
\hline Group III & $153.36 \pm 0.66$ & $173.32 \pm 0.63$ & $193.21 \pm 0.49$ \\
\hline
\end{tabular}

Table.2 Effect of $C$. infortunatum extract on the liver weight, oxidative stress parameters and hepatic biomarker enzymes ( Mean $\pm \mathrm{SE}$ ) level of liver in arsenic induced sub-acute toxicity in rats

\begin{tabular}{|l|l|l|l|l|l|}
\hline Groups & $\begin{array}{l}\text { Liver weight } \\
\text { (Gram) }\end{array}$ & $\begin{array}{l}\text { SOD } \\
\text { (U/gm tissue } \\
\text { (n) }\end{array}$ & $\begin{array}{l}\text { MDA } \\
\text { (nM.MDA } \\
\text { produced/ } \\
\text { mg protein) }\end{array}$ & $\begin{array}{l}\text { ALT } \\
\text { (IU/Litre) }\end{array}$ & $\begin{array}{l}\text { AST } \\
\text { (IU/L) }\end{array}$ \\
\hline Gr. I & $6.24 \pm 0.05$ & $14.22 \pm 0.25$ & $74.13 \pm 0.70$ & $39.15 \pm 0.40$ & $189.03 \pm 0.64$ \\
\hline Gr. II & $5.45 \pm 0.07$ & $12.01 \pm 0.41$ & $86.46 \pm 0.50$ & $69.68 \pm 0.37$ & $223.46 \pm 0.78$ \\
\hline Gr. III & $6.05 \pm 0.04$ & $13.20 \pm 0.23$ & $82.56 \pm 0.60$ & $52.39 \pm 0.62$ & $191.97 \pm 0.43$ \\
\hline
\end{tabular}

Fig.1 Histogram showing effects of $C$. infortunatum extract on body weight (gms) (Mean \pm SE) in arsenic induced sub-acute toxicity in rats . ( $* \mathrm{P}<0.05, * * * \mathrm{P}<0.001)$

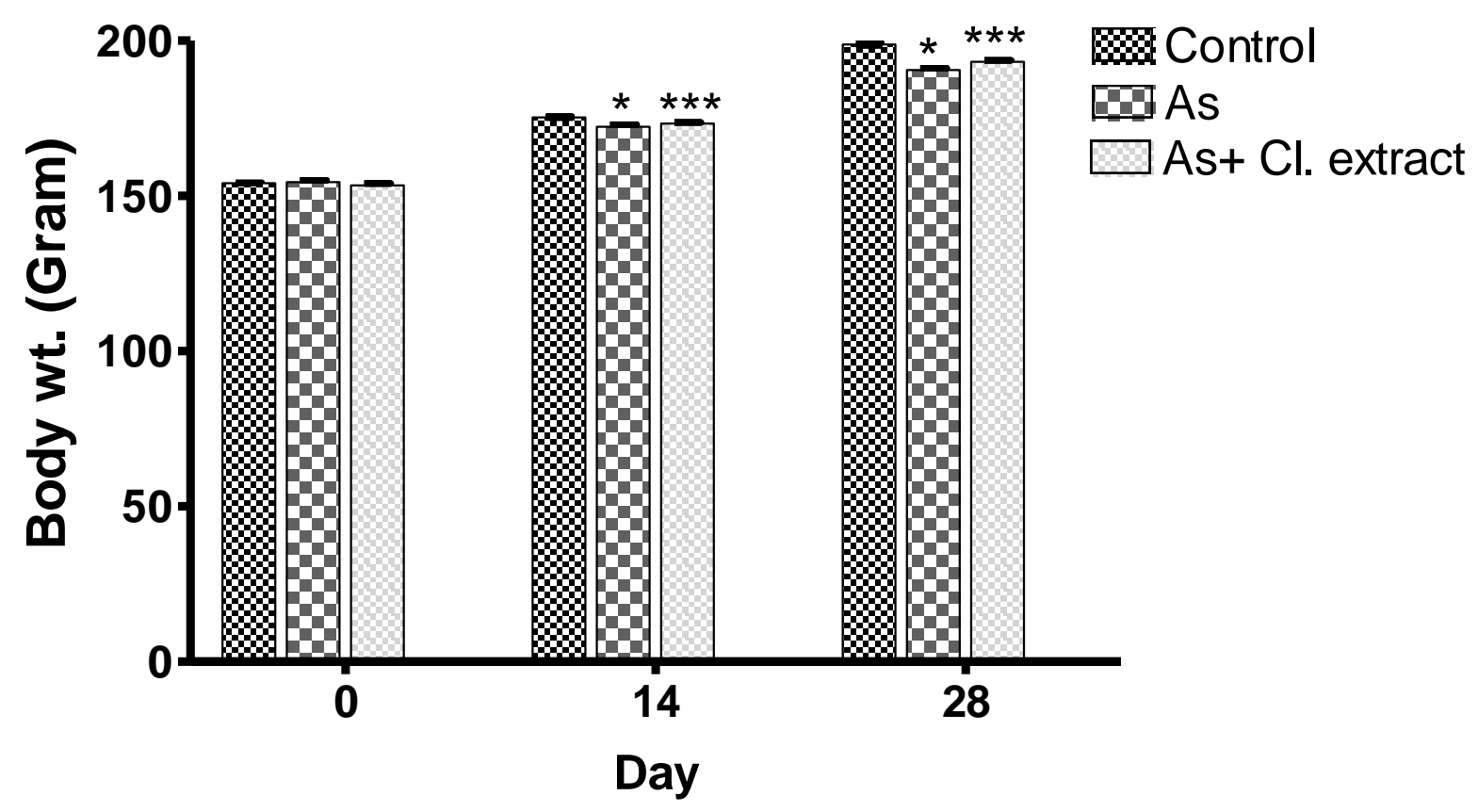


Fig.2 Histogram showing effect of $C$. infortunatum extract on liver weight (gms) ( Mean \pm SE) in arsenic induced sub acute toxicity in rats . $(* \mathrm{P}<0.05, * * * \mathrm{P}<0.001)$

\section{Liver Wt.}

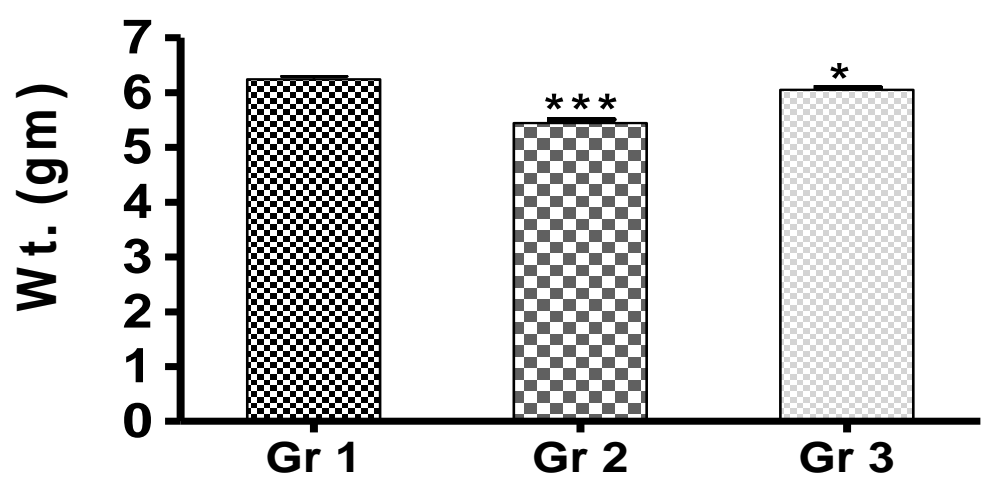

Fig.3 Histogram showing effect of $C$. infortunatum extract on SOD (U/g tissue) in liver in arsenic induced to sub-acute toxicity in rats . $(* * * \mathrm{P}<0.001 ; * \mathrm{P}<0.05 ; \mathrm{P}>0.05$ :NS-Non significant)

\section{SOD}

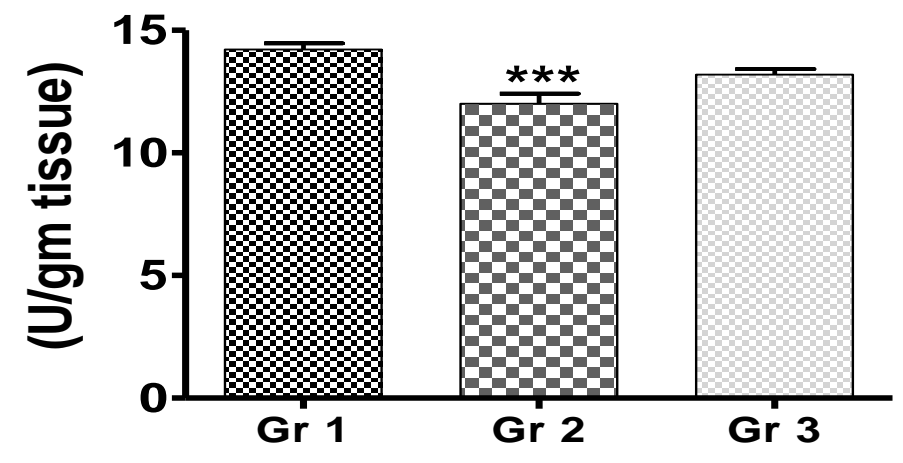

Fig.4 Histogram showing effect of $C$. infortunatum extract on MDA level (nM. MDA produced/ $\mathrm{mg}$ protein) in liver tissue in arsenic induced to sub-acute toxicity in rats. $(* * * \mathrm{P}<0.001)$

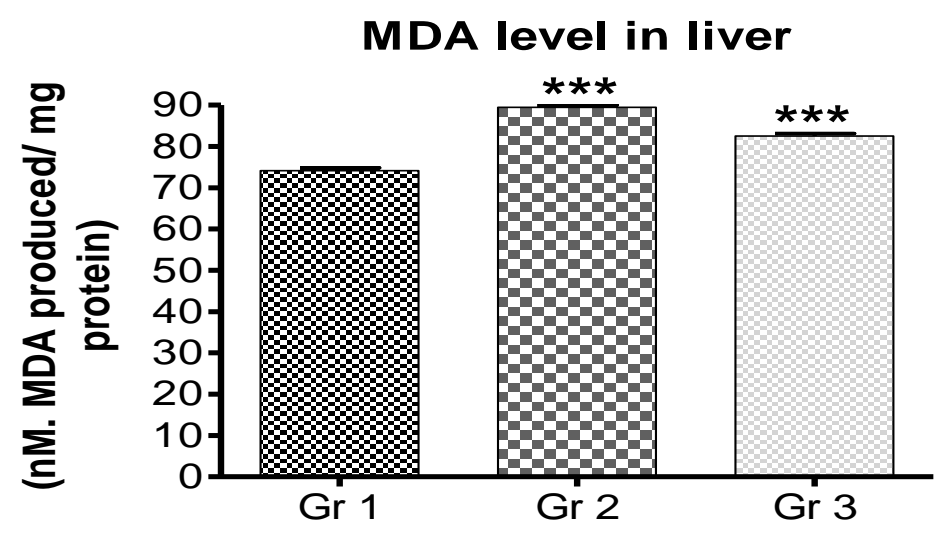


Fig.5 Histogram showing effect of $C$. infortunatum extract on ALT level (IU/Litre) in serum of arsenic induced to sub-acute toxicity in rats. $(* * * \mathrm{P}<0.001)$

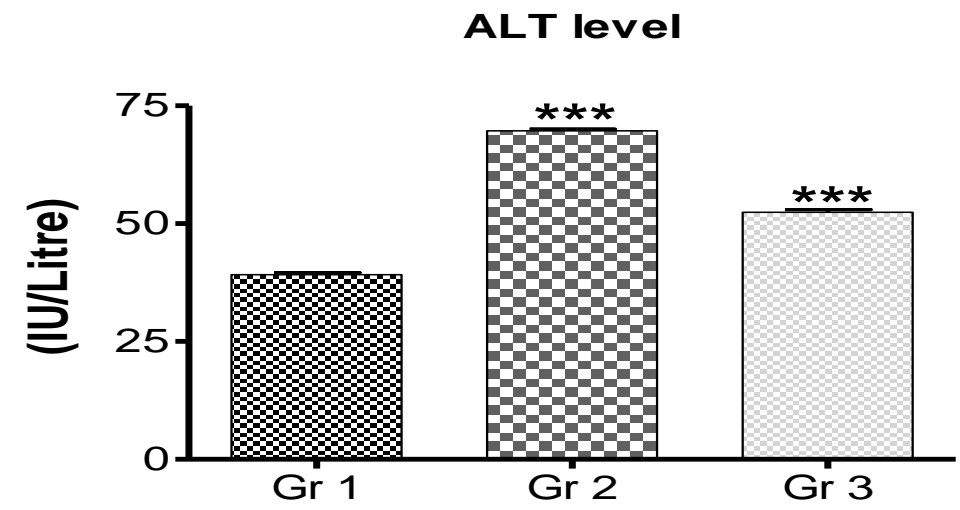

Fig.6 Histogram showing effect of $C$. infortunatum extract on AST level (IU/Litre) in serum of arsenic induced sub-acute toxicity in rats . $(* * * \mathrm{P} 0.001 ; * \mathrm{P}<0.05)$

\section{AST level}

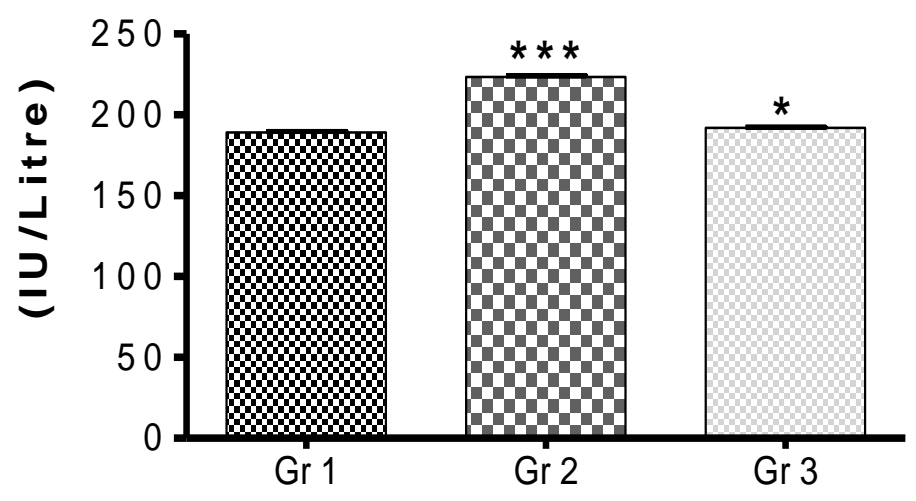

Increase in SOD and decrease in LPO were observed when sodium arsenite was administered with $C I$, which might be due to potent antioxidant activity of $C I$. It might be due to presence of phenolics and flavanoids such as quercetin and kaempferol, having free radical scavenging activity in leaves of $C I$ (Panigrahi et al., 2016).

A significant increase in the activity of serum ALT and AST in treated groups might be due to hepatic damage caused by arsenic in this study. The rise in serum levels of ALT and AST activity has been attributed to the loss of structural integrity of hepatocytes as these enzymes are located in the cytoplasm and are released into circulation after cellular damage (Benzamin, 2010) $)^{\circ}$ The rise in the activity of these enzymes in this study, thus, might have occurred due to hepatic damage caused by arsenic in rats. The decreased ALT level observed in sodium arsenite plus $C I$ treated group may be due to potent hepatoprotective activity (Sannigrahi et al., 2009). The decrease in AST level may be due to hepatocellular membrane stability and prevention of cellular leakage and increasing hepatic regeneration (Kashwa et al., 2011). 
In conclusion, we consider that $C I$ has an eliminating feature on oxyradicals involved in this hepatoprotective effect. Thus, it has been shown in the studies that $C I$ has an eliminating effect on various oxygen species including superoxide anion radical and hydroxyl radicals. It is considered that $C I$ prevents consumption of cellular antioxidant enzyme or prevents loss of enzymatic activity by its eliminating feature. As a result, hepatic damage with the increased of MDA levels and the decreased of antioxidant enzyme (SOD) activities have shown the role of oxidative stress in arsenic toxicity. $C I$ also diminished the apoptosis of hepatic tissues. We exhibited in this study that $C I$ has protective effect and treated oxidative injury in liver tissue. This outcome may derive from the free radical scavenger effects. We concluded that $C I$ may have a useful effect as an important agent for preventing the hepatotoxic damage by arsenic. Our findings may deliver essential facts to better understand the mechanisms underlying the $C I$ effects on arsenic toxicity.

\section{Acknowledgement}

The authors are thankful to the Head of the department, PG department of zoology, Ranchi university, Ranchi for providing necessary facilities to carry out this research work.

\section{Conflict of interest}

There is no conflict of interest.

\section{References}

Anane, R. and Creppy, E.E. 2001. Lipid peroxidation as pathway of aluminium cytotoxicity in human skin fibroblast cultures: Prevention by superoxide dismutase+catalase and vitamins $\mathrm{E}$ and C. Human Exp. Toxicol., 20: 477-481.

Bandyopadhyay, U., Das, D., Bandyopadhyay, D., Bhattacharjee, M. and Banerjee, R.K. 1999. Curr. Sci., 76: 55-63.

Benzamin, Maxim, M. 2010. Outline of veterinary clinical pathology. Ed 3rd Kalyani publishers New Delhi. P 241245.

Droge, W. 2002. Free radicals in the physiological control of cell function. Physiol. Rev., 82: 47-95.

Dymock, W. 1976. Pharmacographia indica.Vol.3, M/S periodical experts, Vivek Vihar, Delhi, PP.79-80.

Jain, S.K. 1988. Evidence for membrane lipid peroxidation during the in vivo again of human erythrocytes. Biochem. Biophysica. Acts., 937: 205-210.

Kant, V., Mehta, M., Varshneya, C. and Chauhan, S. 2011. Induction of oxidative stress by subacute oral exposure of cadmium sulphate in adult poultry. Braz. J. Vet. Pathol., 4(2): 117121.

Kashaw, V., Nema, A.K. and Agarwal, A. 2011. Hepatoprotective prospective of herbal drugs and their vesicular carriers - A review. Int. J. Res. Pharm. Biomed. Sci., 360-374.

Klaassen, C.D. 2001. Heavy metals and heavy metal antagonists. In: Good man and Gillman s the pharmacological basis of therapeutics, ed. Hardman, J.G. and Limbird, L.E. pp. 1851-1875.

Madesh, M. and Balasubramanium, K.A. 1998. Microtitre plate assay for superoxide dismutase using MTT reduction by superoxide. Indian $J$. Biochem. Biophysics, 35: 184-188.

Mylonas, C. and Kouretas, D. 1999. Lipid peroxidation and tissue damage, In 13: 295-309.

Nandi, D., Patra, R.C., Ranjan, R. and Swarup, D. 2008. Role of coadministration of antioxidants in prevention of oxidative injury following sub-chronic exposure to arsenic in rats. Veteri. Arch., 78(2): 113-121. 
Panigrahi, S.S., Prasad, R., Ram, M., Roy, B.K., Sharma, A.K., Singh, K.K. 2016. Clerodendrum infortunatum Linn accelerates wound healing in cutaneous exicisional wound model in rats. J. Vet. Pharmacol. Toxicol., 15(1): 62-67.

Panigrahi, S.S. 2015. Evaluation of wound healing activity of Clerodendrum infortunatum linn. in diabetic rats. M.V.Sc. thesis submitted to RVC, BAU, Kanke, Ranchi-6.

Ramanathan, K., Shila, S., Kumaran, S., Panneerselvam, C. 2003. Protectiverole of ascorbic acid and alpha-tocopherol on arsenic-induced microsomal dysfunctions. Hum. Exp. Toxicol., 22: 129-136.

Sangeetha, B. and Krishna kumari, S. 2010. Tephrosia purpurea (Linn) pers: A folk medicinal plant ameliorates carbon tetrachloride induced hepatic damage in rats. Int. J. Pharma. Biosci., V1(2): 110 .

Sannigrahi, S., Mazumder, U.K., Pal, D., Mishra, S.L. 2009. Hepatoprotective potential of methanol extract of Clerodendrum infortunatum Linn. against $\mathrm{CCl}_{4}$ induced hepatotoxicity in rats. Pharmacog., 9(2): 128-34.

Sarkar, M., Chaudhari, G.R., Chattopadhyay, A., Biswas, N.M. 2003. Effect of sodium arsenate on spermatogenesis, plasma gonadotrophins and testosterone in rats. Asian J. Androl., 5: 27-31.

Segue, J., Gironella, M., Sans, M., Granel, S., Gil, F., Gimeno, M., Coronel, P., Piqui, J.M. and panes, J. 2004. Superoxide dismutase ameliorates TNBS induces colitis by reducing oxidative stress, adhesion molecule expression and leukocyte recruitment into inflamed intestine. J. Leukoc Boil., 76: 537-544

Sharma, A.M., Sharma, K. and Kumar, M. 2007. Protective effect of Mentha piperita against arsenic-induced toxicity in liver of swiss albino mice. Basic. Clin. Pharma. Toxicol., 100(4): 249257.

Shirwaikar, A., Somashekhar A.P., Udupa, A. L., Udupa, S.L. and Somashekhar, S. 2003. Wound healing studies of the Aristolochia bracteolate lam with supportive action of antioxidant enzymes. Phytomed., 10: 558-562.

Stock, J. and Dormandy, T.L. 1971. The autooxidation of human red cell lipidinduced by hydrogen peroxidation. $\mathrm{Br}$. J. Haematol., 20: 95-111.

Stohs, S.J., and Bagachi. 1995. Doxidative mechanisms in the toxicity of metal ions. Free Radic. Biol., 18(2): 321-336.

\section{How to cite this article:}

Pinki Singh, Raju Prasad and Shamshun Nehar. 2017. Ameliorative Potential of Methanolic Extract of Clerodendrum infortunatum Linn. in Arsenic Induced Sub-Acute Hepatotoxicity in Albino Rats. Int.J.Curr.Microbiol.App.Sci. 6(5): 1983-1991. doi: https://doi.org/10.20546/ijcmas.2017.605.222 